University of Nebraska - Lincoln

DigitalCommons@University of Nebraska - Lincoln

Faculty Publications -- Department of English

English, Department of

2014

Veiled Movements in The Vale of Esthwaite

Jack Vespa

Follow this and additional works at: https://digitalcommons.unl.edu/englishfacpubs

Part of the Comparative Literature Commons, English Language and Literature Commons, Modern Literature Commons, and the Reading and Language Commons

This Article is brought to you for free and open access by the English, Department of at DigitalCommons@University of Nebraska - Lincoln. It has been accepted for inclusion in Faculty Publications -Department of English by an authorized administrator of DigitalCommons@University of Nebraska - Lincoln. 
Veiled Movements in The Vale of Esthwaite

\author{
Jack Vespa \\ University of Nebraska-Lincoln
}

The Vale of Esthwaite (1787), Wordsworth's first sustained effort at original composition, was first published in 1940 by Ernest De Selincourt in Poetical Works of Wordsworth as an example of the juvenilia. Among scholars who have treated the De Selincourt version of the poem, Geoffrey Hartman's account in Wordsworth's Poetry, 1787-1814 is the fullest, which argues that The Vale of Esthwaite turns upon the mind of a poet enthralled by nature despite signs that his imagination may well be independent of nature (76-89). Other treatments of De Selincourt's edition appeared in F. W. Bateson, Paul Sheats, Thomas Weiskel, James Averill, Jonathan Wordsworth, Kenneth R. Johnston, and Kurt Fosso. The latest edition appeared in Earlier Poems and Fragments, 1785-1797 (Cornell, 1998), edited by Jared Curtis and Carol Landon, and described by Duncan Wu as "the most accurate and carefully edited text of the poem that we are ever likely to have" (3). One can learn much about Wordsworth's evolving practice from this text, experimenting as he does with description, moral encomia, and personal reflection/retrospection inspired by Virgil's Georgics and contemporary Gothic and local color. Incomplete and underdeveloped as the poem is, it parleys an initiation whereby the young poet recognizes his poetic calling, as Jonathan Wordsworth first surmised in "Two Dark Interpreters: Wordsworth and De Quincey”(224).

Comprised of three major sections or movements in manuscript, the poem could be read as an anthology of visual and visionary scenes, as Landon and Curtis have remarked, but there is a certain cleverness about it that makes it more than discrete imitative exercises. The "argument," to adapt a Romantic convention, may be sketched hypothetically as follows:

View of Esthwaite-Superstition-Spirits, as Might Be Heard by a Minstrel-Mystic Twilight-Veil of Night-MelancholyPower of Fancy-Storm Visions-Spectral Visitations-Remembrance of Grief following the Death of the Author's Father-Whispering Voice-Hope for Peace at the Close of Life-Faith in Friendship-Consolation in Nature and Memory-Homage to Native Region-Filial Love-Homage to a Friend.

These headings could be faithful to the poem as it exists in manuscript and as the young Wordsworth might have formulated them for An Evening Walk and Descriptive Sketches (both 1793). For all of the lapses or shifts in theme, tense, and tone, particularly in the third movement, a line runs through the first two movements, one that turns upon the young poet's place in literary tradition, which in turn impacts the final movement.
Wordsworth cleverly and self-consciously acknowledges over the course of the poem the literary tradition that precedes him, and gestures toward the origins of his own poetic calling with an opening verse paragraph that I call a "View of Esthwaite" (1-24) that foregrounds the georgic inquisitiveness inflecting the first section by describing some of "the landskip's varied treasure" (2). The narrator finds himself in the "gloomy glades" of "Superstition" (25 ff.), where "the ringing harp" of "druid Sons" (31-32), moves him to ask "Why roull on me your glaring eyes/Why fix on me for sacrifice" (33-34, echoing Wordsworth's Irregular Fragment). The question imparts a sense of foreboding, trading as the passage does in English druidic folklore. "Then musing onward would I stray/Till every rude sound died away," the speaker observes to lead off verse paragraphs that I have tagged "Spirits, as Might Be Heard by a Minstrel” (43 ff.), which exhibit further awareness of other English folklore along with a knowledge of Virgilian and contemporary poetics:
And oft as ceased the owl his song
That screamed the roofless walls among
Spirits yelling from their pains
And lashes loud and clanking chains
Were heard by minstrel led astray
Cold wading thro' the swampy way
Who as he flies the mingled moan
Deep sighs his harp with hollow groan
He starts the dismal sound to hear
Nor dares revert his eye for fear
Again his harp with thrilling chill
Shrieks at his shoulder sharp and shrill
Aghast he views, with eyes of fire
A grisly Phantom smite the wire. ... (51-64)

Wordsworth's poet turns briefly postmodern as he rehearses familiar images and motifs such as "Spirits yelling from their pains/And lashes loud and clanking chains" (like Beattie's Minstrel along with Virgil's Aeneid) that are germane to a "minstrel led astray" whose "harp" or sensibility is susceptible to a lively imagination, particularly when "fearful." He fears the evil that supposedly follows the "scream" of an owl, an omen, as Landon and Curtis note at a later recurrence of the image (432n) that applies equally as well here. The ironic distance for which Wordsworth strives is only imperfectly achieved, but seems to be deliberate, as in subsequent lines in which the speaker suggests that such gothicism is inspired by the sound of a "pebble . . . gingling" down on mountainside, dislodged by a "flickering dove/[That] Broke from the rustling boughs above" or perhaps some "straggl'd sheep ... starting wildly from its sleep," before the pebble falls "in the Rill below" (65-74). "Superstition" soon gives way to "Mystic Twilight" (75 ff.) once the speaker observes "Lone wandering oft by Esthwaite's [stream]/My soul has felt the mystic 
dr[eam]" (75-76), and is followed by the "Veil of Night" (95 ff.) and "Melancholy" (123 ff.), as the poet settles into a pastoral repose typical of evening-twilight. The foregoing couplet, with its conjectural emendations of "[stream]" and "dr[eam]," offers an apt emblem for the young poet's eddying sensibility, not to mention his awareness of Virgil's verbal and sentimental legacies. Once in repose, he duly notes "o'er the heart we feel/A Tender Twilight softly steal" (127-28), reinforcing his self-conscious awareness of contemporary poeticisms. The vale features a topography of scenes and texts revisited, which offers a convenient cartography of Wordsworth's formative influences.

The "mystic dream" to which the young poet is given becomes manifest in the second movement of the poem, much as if the sense of foreboding articulated earlier was a portent, despite its ironic treatment afterward. Wordsworth restages images and motifs broached earlier in the poem in a manner reminiscent of Virgil in the Georgics.

As the second section opens with verse paragraphs that I have grouped under the heading "Power of Fancy" (133 ff.), an owl that "screams her song" (134) interrupts the poet's repose, and recalls the owl "That screamed the roofless walls among" in the first movement. The poet's gaze turns to a mansion during a storm, where the Gothic atmosphere exacerbates his "fear struck mind" (145). While "Pleasures of a softer kind" (178), such as the vale of Grasmere, also engage his developing imagination, the speaker gravitates toward some "Storm Visions" (191 ff.), as I have characterized the two verse paragraphs that follow, including the Gothic mansion calling to mind the "portraits" (205) in The Castle of Otranto along with some nondescript "daemons of the Storm" (211). The speaker flees, only to encounter a "Spectre" (219), which inspires the heading for the last verse paragraph of this movement, "Spectral Visitations" (215 ff.). "And on his feeble arm he bore/What seem'd the poet's harp of yore" (226-27), the poet observes, which recalls the minstrel upon whom he mused earlier.

He wav'd his hand and would have spoke But from his trembling shadow broke Faint murmuring sad and hollow moans As if the wind sigh'd through his bones

Now as we wandered through the gloom In Black Helvellyn's inmost womb The Spectre made a solemn stand Slow round my head thrice waved his [hand] And cleaved mine ears then swept his [lyre] That shriek'd terrific shrill an[d] [dire] Shudder'd the fiend. The vault a[lo]ng Echoed the loud and dismal song.

'Twas done. The scene of woe was o'er My breaking soul could bear no more. . . . (228-231, 24251)
The poet finds himself in a situation eerily similar to the one involving the generic minstrel that he rehearsed earlier in the poem, only this time it is he who has the impressionable sensibility and lively imagination that is responsive to fear. Once his repose is interrupted by the scream of an owl, superstition and fear play upon his imagination, intriguingly enough, the force of which eventually summons a minstrel spectre whose intensity harrows the young poet. Once inside "Black Helvellyn's inmost womb," the young poet/minstrel generates a "scene of woe" befitting his embryonic imaginative impulse, along with a vision of the battle of Dunmail Raise and the "Ghosts" of Edmund of Saxony and Dunmail of Cumbria, as he mentions shortly afterward (261 ff.). While $\mathrm{Wu}$ and Hughes take the subterranean space of Helvellyn as a figure for the poetic imagination too, they emphasize the connection between death and creativity in Wordsworth. Gravil reads the moment as part of a druidic reverie, by contrast, which comprises a larger pattern of what he calls the poet's "bardic vocation" that informs his alternative account of Wordsworth's calling.

Wordsworth manages these Gothic effects through repetition primarily, describing the spectral, if conjectural, "lyre" as one "That shriek'd terrific shrill", echoing diction that he used to describe the generic minstrel that he mentioned in the first section of the poem-whose "harp with thrilling chill/Shrieks at his shoulder sharp and shrill"-as well as emulation, emphasizing a subterranean journey (like Williams's Irregular Fragment and John and Ann Letitia Aikin's fragment Sir Bertrand) and how the poet's "breaking soul could bear no more” (echoing Williams's Peru and An American Tale). The topography of scenes and texts revisited here and elsewhere in the poem points up the extent to which Wordsworth's poetic voice is veiled or muffled by the voices of his precursors and contemporaries.

By re-staging earlier images and motifs in a new context, Wordsworth gestures toward an initiation rite that becomes personal in the last movement of the poem. The poet characterizes the minstrel spectre as "my grisly guide" (256) late in the second section-akin to the "grisly Phantom" encountered by the generic minstrel, which further reinforces the parallel between the two episodes. Wordsworth's minstrel ascribes responsibility for the ghosts that he glimpses during the encounter to the minstrel spectre, and concludes with

\footnotetext{
With dismal yell and savage scowl

While Terror shapeless rides my soul

Full oft together are we hurl'd

Far Far amid the shadowy world-

[And since that hour the world unknown

The world of shades is all my own] $(266-71)$
}

The closing emendation, a marginal entry that Landon and Curtis consider tentative because it is not clear whether it should follow or replace lines 266-71, points up the world of the departed that preoccupies the speaker for much of the 
third section of the poem. It is as if the visionary "scene of woe," with its shades of ancient "Britons" (263) who inhabit the poet's imagination, leads him to brood upon death and dying and inspires an autobiographical turn in the process, devoted as the last section is to "this vale of woe" (309), in fine Virgilian fashion, and reflection upon Wordsworth's late father and mother as well as his own future death.

As the third movement opens, Wordsworth's young poet eschews the minstrelsy of the previous two sections in favor of a more intimate idiom, striving for a confessional immediacy and descriptive display that is more germane to modernized pastoral repose in the age of Sensibility, much as if he now intuits what should be his own poetic calling. The repose that marked the end of the first section resumes, and turns elegiac with the verse paragraph that opens this last movement, one that I have labeled "Remembrance of Grief following the Death of the Author's Father” (272 ff.), marking another riff to the undersong of melancholy that resonates so throughout the century. The young poet's elegiac memory of the loss of his father gives way to an intimation of a future reunion with loved ones ("Whispering Voice," 296 ff.) before seguing to a proleptic meditation upon his own death ("Hope for Peace at the Close of Life," $304 \mathrm{ff}$.), interrupted briefly by an apostrophe to a friend and friendship that involves Wordsworth's Hawkshead schoolmate John Fleming ("Faith in Friendship," $324 \mathrm{ff}$.), which perhaps enables the poet to endure human mortality and transience ("Consolation in Nature and Memory," $336 \mathrm{ff}$.), before indulging in a series of homages that extol Esthwaite, his mother, his sister, and Fleming again, respectively. The sequence I have outlined here strives for an interiority anticipating his mature descriptive-meditative idiom, undercut by the various homages improvised at the close, which may signal some confusion on Wordsworth's part with how to end the poem, as Landon and Curtis observe (409). For all of the fragmentation at the end, inadvertently veiling or obscuring the poet's metamorphosis, the eulogy of Esthwaite (354 ff.), which is the best known passage from the poem owing to Wordsworth's publication of a revision as an example of his juvenilia in his collected Poems (first appearance, 1815) along with his re-workings of it for the 1799 and 1850 Prelude, retains a certain charm, and offers a glimpse into a new figure of the poet in the young initiate:

Yet if Heav'n bear me far away

To close the Evening of my day

Even while my body pants for brea[t]h

And shrinks at the dart of dea[th]

My soul shall cast the wistful view

The lingering look alone on you

As Phoebus when he sinks to rest

Far on the mountains in the west

While all the vale is dark between

Ungilded by his golden sheen

A lingering lustre softly throws

On the dear hills where first he rose. (354-365)
The young poet, seeking the most apt language of the heart, shares his enduring affinity for his native region, lovingly parleyed by the line "The lingering look alone on you" (echoing Gray's "Elegy") and the closing couplet, the liquid or palatal $/ 1 / \mathrm{s}$ evoke a catch in the throat, much as if his affection becomes too palpable momentarily. He speaks to Esthwaite with an intimacy one might share with a parent, sibling, friend, or lover. In doing so, Wordsworth parleys an alternative figure of the poet, one that may be confidante, which departs considerably from the empiricists, enthusiasts, and wanderers as well as bards and minstrels that circulate during the century. This figure of the poet is an inquisitive and contemplative one, much like Virgil before him, and a self-reflexive one too, which distinguishes him from his classical precursor. He speaks much as if he were a friend, lover, or sibling, intimating his heart's truth.

This exaltation of Esthwaite, coupled with the first turn to Fleming earlier in the third section-"Friend of my soul! for whom I feel/What words can never half reveal. .."(324 ff.) - and the turn to his sister shortly after the eulogy of Esthwaite-"Sister for whom I feel a love/What warms a brother far above. . ."(380 ff.) - together showcase a poet who articulates or intimates heartfelt emotions with an interiority that tweaks if not transcends the georgic, pastoral, and sentimental traditions that he inherits. These moments mark an early appearance of materials and themes that will intrigue Wordsworth throughout his career, which have their public debut in An Evening Walk. The poet's local and familial sympathies, in turn, augur his attention to local, national, and/or international communities, including connections to these communities as well as the changes they undergo over time, which figure prominently in his (and his sister's) mature poetry.

Wordsworth continues to brood upon his poetic calling after The Vale of Esthwaite as he experiments further with form, genre, and mode as well as diction, figures, rhythm, and topoi in search of a singular descriptive-meditative idiom. While the emulation to which a young poet is prone can be problematic, it allows him to immerse himself in the georgic imagination, as it works out. Following his initial drafting of The Vale of Esthwaite in 1787, Wordsworth turned to translations of Virgil's Georgics in 1788, among other projects that comprise his juvenilia, as Bruce Graver discusses in "Wordsworth's Georgic Beginnings," analyzing Wordsworth's translations of the Georgics and their place in the formation of his descriptive style. The opening rectos and verso of DC MS. 5 show the young poet focusing upon the georgic poet's homage to country life (Georgics II.458 ff.), notably, and occasionally finding his own way with words in the process:

To them the arts of falsehood are unknown And nature's various wealth is all their own [ ]

And living lakes and caves of cool recess

All nature smiles 
They find a Tempe cool in every vale At languid noon the far off Heifer lows While calm in secret they repose

Thither the tender charities retire There true Religion lights her purest fire On [1 ${ }^{\mathrm{r}}$; cf. Georgics II.467-73]

Why in far cave twinkling with many a star [ ]

In Winter why so soon to th' Ocean stream Slopes the pale [weary] sun his westering team Why in her cave of Cloud so long remains

Lingers Night below th' horiz[on's] bou[nd] [1"; cf. Georgics II.477, 481-82]

There let the deep'ning forest still and dead Hang in deep solemn twilight o'er my head Ah What god in that cool vale [my form will hide] Where $\mathrm{H}[\mathrm{ae}]$ mus spreads her dark'ning umbrage wide Let me lie

Far in some vale on $\mathrm{H}[\mathrm{ae}] \mathrm{mus}$ cool and high There let the deep'ning forest still and dead Hang in dim solemn twilight o'er my head [2; ;f. Georgics II.485-89] ${ }^{2}$

As Wordsworth turns to lines concerning the georgic poet's secondary aspirations on $2^{r}$, including the mountain range "H[ae]mus," the poet impresses something of his own descriptive technique by writing "There let the deep'ning forest still and dead/Hang in deep solemn twilight o'er my head," extending Virgil's description as Landon and Curtis note (618), superimposing an alternative emotional heft on Virgil's Greek place-names, deities, nymphs, and the Hellenic pastoral which he considers the contemplative poetic calling. Wordsworth uses Virgil's sentimental legacy as a touchstone in working toward his own singular descriptive-meditative idiom.

While Wordsworth's experiments encompass more than translations of the Georgics and The Vale of Esthwaite in the manuscripts of his juvenilia that survive, I believe he may be characterized as a Romantic humanist whose Virgilian muse is mediated by Virgil's 17th- and 18th-century British interpreters, whose descriptive, topographical, and prose modulations of the georgic yield figures of the poet such as bard, minstrel, empiricist, enthusiast, and wanderer, many of whom strive to build upon Virgil's verbal and sentimental legacies. And as Wordsworth experiments with georgic and pastoral topoi, along with sentimental topoi as the age of Sensibility unfolds, one can glimpse the beginnings of a new figure of the poet, who may be read as a confidante peeking out of The Vale of Esthwaite, and heralding the poet that is to come.
${ }^{1}$ All quotations from The Vale of Esthwaite are from the Cornell edition of Wordsworth titled Earlier Poems and Fragments, 1785-1797, edited by Landon and Curtis. Their reading text of the poem proper is drawn from MS. A (signifying Dove Cottage MS. 3) and is considerably shorter than that in the earlier edition of the poem by De Selincourt, owing to a "misapprehension" that led the latter to proffer a significantly longer version collated from multiple manuscripts (407-21). Echoes of Milton, Thomson, Beattie, Thomas Gray, and Williams that have been documented by Landon and Curtis will be acknowledged parenthetically in my argument. In all quotes, italic emphases are added)

${ }^{2}$ My text of the translations is also from Earlier Poems and Fragments, $1785-1797$ by Landon and Curtis. Wordsworth does not translate this passage or others from Virgil systematically, interspersed as they are throughout DC MSS. 5, 6, and 7 with other lines of poetry.

\section{WORKS CITED AND CONSULTED}

Averill, James. Wordsworth and the Poetry of Human Suffering. Cornell UP, 1980; Bateson, F. W. Wordsworth: A Re-interpretation. 2nd ed. Longman's, 1956; Fosso, Kurt. “A 'World of Shades': Mourning, Poesis, and Community in William Wordsworth's The Vale of Esthwaite." Modern Language Review 93.3 (July 1997) 629-41; Graver, Bruce. "Wordsworth's Georgic Beginnings." Texas Studies in Literature and Language 33.2 (1991)137-159; Gravil, Richard. Wordsworth's Bardic Vocation, 1787-1842. Palgrave MacMillan, 2003; Hartman, Geoffrey. Wordsworth's Poetry, 1787-1814. 1971. Harvard UP, 1987; Hughes, John. "The Poetics of Orphanhood: Wordsworth's 'Salisbury Plain,' 'The Vale of Esthwaite,' and 'Tintern Abbey'." Romanticism, 14.3 (2008) 219-31; Johnston, Kenneth R. The Hidden Wordsworth: Poet, Lover, Rebel, Spy. Norton, 1998; Sheats, Paul. The Making of Wordsworth's Poetry, 1785-1798. Harvard UP, 1973; Sutherland, Kathryn. "The Native Poet: the Influence of Percy's Minstrel from Beattie to Wordsworth." Review of English Studies 132 (1982) 414-33; Vespa, Jack. "Georgic Inquisitiveness, Pastoral Meditation, Romantic Reflexivity: 'Nutting' and the Figure of Wordsworth as Poet," Genre 38 (Spring/Summer 2005) 1-44. Virgil. Virgil. Eclogues. Georgics. Aeneid. Rev. ed. 1935. Trans. H. Rushton Fairclough. The Loeb Classical Library. 2 vols. Harvard UP, 1947; Weiskel, Thomas. The Romantic Sublime. The John Hopkins UP, 1976; Wordsworth, Jonathan. "Two Dark Interpreters: Wordsworth and De Quincey." The Age of William Wordsworth: Critical Essays on the Romantic Tradition. Eds. Kenneth R. Johnston and Gene Ruoff. Rutgers UP, 1987. 214-238; Wordsworth, William. Early Poems and Fragments 1784-1797. Eds. Jared Curtis and Carol Landon. The Cornell Wordsworth. Cornell UP, 1998; The Poetical Works. Eds. Ernest de Selincourt and Helen Darbishire. 5 vols. Clarendon P, 1940-49; Wu, Duncan. Wordsworth: An Inner Life. Blackwell Publishers, 2002. 